\title{
GMR
}

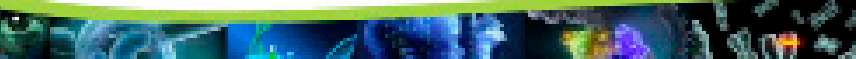

\section{G/C polymorphism in Toll-like receptor 4 results in increased susceptibility to bladder cancer}

\author{
B. Wan, J. Tan, Q. Zeng, L.Y. He, Y. Gan, Y.B. Dai and K. Yao \\ Department of Urology, The Third Xiangya Hospital of Central South University, \\ Changsha, Hunan, China \\ Corresponding author: K. Yao \\ E-mail: dr_yaokun@126.com
}

Genet. Mol. Res. 14 (4): 15482-15487 (2015)

Received June 20, 2015

Accepted September 20, 2015

Published November 30, 2015

DOI http://dx.doi.org/10.4238/2015.November.30.26

\begin{abstract}
In this study, the association between the $729 \mathrm{G} / \mathrm{C}$ polymorphism in Toll-like receptor 4 (TLR4) and the risk of bladder cancer was investigated. A total of 376 patients with bladder cancer and 380 healthy volunteers from the Third Xiangya Hospital of Central South University (China) were enrolled in this study between January 2008 and February 2014. The TLR4-729G/C polymorphism was detected by the polymerase chain reaction-restriction fragment length polymorphism assay. There was a significant difference in the distribution of the TLR4-729G/C genotype between bladder cancer patients and healthy controls $(P<0.001)$. Our analysis showed that the GC genotype $(\mathrm{OR}=2.99 ; 95 \% \mathrm{Cl}=1.01-4.81$, $\mathrm{P}=0.046)$ and $\mathrm{CC}$ genotype $(\mathrm{OR}=3.67 ; 95 \% \mathrm{Cl}=2.11-7.27, \mathrm{P}=0.017)$ were significantly associated with increased bladder cancer risk when the GG genotype served as a reference. Furthermore, carriers of the $\mathrm{C}$ allele had a significantly increased risk of developing bladder cancer $(\mathrm{OR}=3.89$; $95 \% \mathrm{Cl}=2.88-8.53 ; \mathrm{P}=0.009$ ). Our results suggest a correlation between the TLR4-729G/C polymorphism and the risk of developing bladder cancer in this Chinese population.
\end{abstract}

Key words: Bladder cancer; Toll-like receptor; Gene polymorphism; PCR-RFLP 


\section{INTRODUCTION}

Bladder cancer is the most common malignancy of the urinary tract, ranking sixth in cancer incidence worldwide, and is more prominent in men than women (Shariat et al., 2010; Siegel et al., 2015). Bladder cancer has a complicated etiology and there are several major risk factors for bladder tumorigenesis, including chemical and environmental exposures and genetic factors $(\mathrm{Wu}$ et al., 2008).

Toll-like receptor 4 (TLR4) belongs to the toll-like receptor (TLR) family, which is an important class of pattern recognition receptors (PRRs) in humans that recognize pathogen-associated molecular patterns (Ishihara et al., 2004). The human TLR4 gene is located on chromosome 9 (9q32-q33) and consists of four exons and three introns with an overall length of approximately 19 $\mathrm{Kb}$ (Horie et al., 2009). TLR4 is critical in the recognition of viruses and bacteria, serving as a key immune system effector. Dysregulation of TLR4 signaling owing to single nucleotide polymorphisms (SNPs) may alter ligand binding and the balance between pro- and anti-inflammatory cytokines, thereby increasing the risk of chronic inflammation and cancer.

The potential association between TLR4 genetic polymorphisms and the risk of breast cancer, gastric cancer, prostate cancer, ovarian cancer, hepatocellular carcinoma (HCC), cervical cancer, and colorectal cancers has been investigated earlier (Zhu et al., 2013; Zhou et al., 2014; Jiang et al., 2014; Zidi et al., 2014a,b; Kopp et al., 2015). However, there has been little research on the association between the $729 \mathrm{G} / \mathrm{C}$ polymorphism in the TLR4 gene and the risk of bladder cancer.

\section{MATERIAL AND METHODS}

\section{Study subjects}

Our study was approved by the Ethics Committee of the Third Xiangya Hospital of Central South University (China), and all research subjects provided informed consent. A total of 376 patients with bladder cancer and 380 healthy volunteers from the Third Xiangya Hospital of Central South University were enrolled in this study between January 2008 and February 2014. All cases of bladder cancer were histopathologically confirmed and staged according to the tumor-nodemetastasis staging system of the Union for International Cancer Control. All cases and controls completed a face-to-face questionnaire to obtain information on demographic characteristics (age and gender), history of smoking, alcohol consumption, and family history of cancer.

\section{Genotyping}

Genomic DNA was extracted from venous blood samples using the QIAamp DNA blood mini kit (Qiagen, Germany) and then stored at $-80^{\circ} \mathrm{C}$ until use. The TLR4 $-729 \mathrm{G} / \mathrm{C}$ polymorphism was detected by the polymerase chain reaction-restriction fragment length polymorphism (PCRRFLP) assay. In brief, PCR was performed in a $20 \mu \mathrm{L}$ mixture containing 200 ng genomic DNA, 1.5 $\mathrm{mM} \mathrm{MgCl}, 0.5 \mu \mathrm{M}$ primer, $2 \mu \mathrm{L} 10 \mathrm{X}$ PCR buffer, $0.2 \mathrm{mM}$ dNTP, and 1.2 U Taq polymerase. After an initial denaturation at $95^{\circ} \mathrm{C}$ for 5 min, DNA was amplified by 30 cycles of $95^{\circ} \mathrm{C}$ for $30 \mathrm{~s}, 55^{\circ} \mathrm{C}$ for $30 \mathrm{~s}$, and $72^{\circ} \mathrm{C}$ for $30 \mathrm{~s}$, with a final elongation step at $72^{\circ} \mathrm{C}$ for $5 \mathrm{~min}$ on the GeneAmp PCR System 9700 . The digested PCR products were separated on $2 \%$ agarose Tris-borate-EDTA gels and stained with ethidium bromide. 


\section{Statistical analysis}

Allele and genotype frequencies were calculated by the gene counting method. ORs and $95 \% \mathrm{Cls}$ were used to represent the risk of developing bladder cancer. ORs were calculated using multivariate logistic regression analyses after adjusting for age and gender. All statistical tests were two-sided probability tests and a $P$ value of less than 0.05 was considered statistically significant. Statistical analyses were performed using the SPSS 18.0 software (SPSS, Chicago, IL, USA).

\section{RESULTS}

\section{Characteristics of the study population}

The frequency distribution of demographic characteristics in the 376 bladder cancer patients and 380 healthy controls is shown in Table 1. The patients and controls were shown to be adequately matched for age $(P=0.166)$ and $\operatorname{sex}(P=0.481)$. The frequency of relatives with cancer was higher in the bladder cancer patients than in the controls $(22.07$ vs $11.84 \%$; $P<0.001)$. No significant difference in tobacco $(P=0.283)$ or alcohol $(P=0.549)$ consumption was found between the bladder cancer patients and healthy controls.

\begin{tabular}{|c|c|c|c|c|c|}
\hline \multirow[t]{2}{*}{ Characteristic } & \multicolumn{2}{|c|}{ Bladder cancer patients $(\mathrm{N}=376)$} & \multicolumn{2}{|c|}{ Healthy controls $(\mathrm{N}=380)$} & \multirow[t]{2}{*}{$P$ value } \\
\hline & $\mathrm{N}$ & $\%$ & $\mathrm{~N}$ & $\%$ & \\
\hline \multicolumn{6}{|l|}{ Age (years) } \\
\hline$\geq 60$ & 189 & 50.27 & 211 & 55.53 & \multirow[t]{2}{*}{0.166} \\
\hline$<60$ & 187 & 49.73 & 169 & 44.47 & \\
\hline \multicolumn{6}{|l|}{ Gender } \\
\hline Male & 254 & 67.55 & 266 & 70.00 & \multirow{2}{*}{0.481} \\
\hline Female & 122 & 32.45 & 114 & 30.00 & \\
\hline \multicolumn{6}{|c|}{ Family history of cancer } \\
\hline Yes & 83 & 22.07 & 45 & 11.84 & \multirow[t]{2}{*}{$<0.001$} \\
\hline No & 293 & 77.93 & 335 & 88.16 & \\
\hline \multicolumn{6}{|c|}{ Tobacco consumption } \\
\hline No & 241 & 64.10 & 258 & 67.89 & \multirow[t]{2}{*}{0.283} \\
\hline Yes & 135 & 35.90 & 122 & 32.11 & \\
\hline \multicolumn{6}{|c|}{ Alcohol consumption } \\
\hline No & 139 & 36.97 & 149 & 39.21 & \multirow[t]{2}{*}{0.549} \\
\hline Yes & 237 & 63.03 & 231 & 60.79 & \\
\hline
\end{tabular}

\section{Allele and genotype frequency of the TLR4-729G/C polymorphism}

Table 2 summarizes the genotype and allele distributions of the TLR4-729G/C polymorphism in bladder cancer patients and the healthy control group. The observed genotype frequencies of the TLR4-729G/C polymorphism were in agreement with the Hardy-Weinberg equilibrium in both the bladder cancer and control groups (both P > 0.05). Genotypes GG, GC, and CC were detected in $268(71.28 \%), 84(22.34 \%)$, and $24(6.38 \%)$ of 376 bladder cancer patients and in $331(87.11 \%)$, $47(12.37 \%)$, and $2(0.53 \%)$ of 380 healthy control samples. There was a significant difference in the distribution of the TLR4-729G/C genotype between bladder cancer patients and healthy controls $(P<0.001)$. The frequency of allele $G$ was $620(82.45 \%)$ and allele $C$ was $132(17.55 \%)$ in the bladder cancer cases, and $709(93.29 \%)$ and $51(6.71 \%)$ in the healthy controls, respectively. 
The frequency of the $\mathrm{C}$ allele was significantly higher in the bladder cancer group as compared to the control group $(P<0.001)$.

Table 2. Allele and genotype frequencies of the TLR4-729G/C polymorphism in bladder cancer patients and healthy controls.

\begin{tabular}{lccccc}
\hline & \multicolumn{2}{c}{ Bladder cancer patients $(\mathrm{N}=376)$} & \multicolumn{1}{c}{ Healthy controls $(\mathrm{N}=380)$} & P value \\
\hline Genotype & $\mathrm{N}$ & $\%$ & $\mathrm{~N}$ & $\%$ & $<0.001$ \\
GG & 268 & 71.28 & 331 & 87.11 & \\
GC & 84 & 22.34 & 47 & 12.37 & \\
CC & 24 & 6.38 & 2 & 0.53 & $<0.001$ \\
Allele & & & & 93.29 & \\
G & 620 & 82.45 & 51 & 6.71 & \\
C & 132 & 17.55 & &
\end{tabular}

\section{Association between the TLR4-729G/C polymorphism and bladder cancer susceptibility}

Our analysis showed that the occurrence of the $\mathrm{GC}(\mathrm{OR}=2.99 ; 95 \% \mathrm{Cl}=1.01-4.81, \mathrm{P}$ $=0.046)$ and $\mathrm{CC}$ genotype $(\mathrm{OR}=3.67 ; 95 \% \mathrm{Cl}=2.11-7.27, \mathrm{P}=0.017)$ significantly correlated with increased bladder cancer risk when the $\mathrm{GG}$ genotype served as the reference. The GC+CC genotype was significantly associated with increased bladder cancer risk under the dominant model $(\mathrm{OR}=3.18 ; 95 \% \mathrm{Cl}=2.24-6.19, \mathrm{P}=0.016)$. Furthermore, carriers of the $\mathrm{C}$ allele were likely to have a significant increase in risk of bladder cancer $(\mathrm{OR}=3.89 ; 95 \% \mathrm{Cl}=2.88-8.53 ; \mathrm{P}=0.009)$. These results are summarized in Table 3.

Table 3. Correlation between the TLR4-729G/C polymorphism and risk of bladder cancer.

\begin{tabular}{|c|c|c|c|c|}
\hline & Bladder cancer patients & Healthy controls & OR $(95 \% \mathrm{Cl})$ & $P$ value \\
\hline \multicolumn{5}{|c|}{ General genotype } \\
\hline GG & 268 & 331 & 1.00 (Reference) & \\
\hline GC & 84 & 47 & $2.99(1.01-4.81)$ & 0.046 \\
\hline $\mathrm{CC}$ & 24 & 2 & $3.67(2.11-7.27)$ & 0.017 \\
\hline \multicolumn{5}{|c|}{ Dominant genotype } \\
\hline GG & 268 & 331 & 1.00 (Reference) & \\
\hline $\mathrm{GC}+\mathrm{CC}$ & 108 & 49 & $3.18(2.24-6.19)$ & 0.016 \\
\hline \multicolumn{5}{|c|}{ Recessive genotype } \\
\hline$G G+G C$ & 352 & 378 & 1.00 (Reference) & \\
\hline $\mathrm{CC}$ & 24 & 2 & $2.35(0.73-5.75)$ & 0.298 \\
\hline \multicolumn{5}{|c|}{ Allele frequency } \\
\hline G & 620 & 709 & 1.00 (Reference) & \\
\hline C & 132 & 51 & $3.89(2.88-8.53)$ & 0.009 \\
\hline
\end{tabular}

\section{DISCUSSION}

Cancer is a multifactorial disorder that stems from the combined effects of various genetic, environmental, and behavioral risk factors. These factors are unique to each individual and studies have shown that environmental factors such as diet and smoking can be more important risk factors than genetic susceptibility (Hahn and Weinberg, 2002). The genomic DNA sequences of two unrelated people are quite similar, differing in only $0.1 \%$ of total DNA content. This percentage is important because it includes the genetic variants that influence 
the susceptibility of individuals to different diseases and response to drugs and environmental factors (Levy et al., 2007).

Chronic infection and inflammation are important factors contributing to tumorigenensis and tumor progression (Balkwill and Coussens, 2004). TLRs play a pivotal role in the immune response and are involved in the regulation of inflammatory reactions and activation of the adaptive immune response to eliminate infectious pathogens and cancer debris (Akira et al., 2001; Akira and Takeda, 2004; Krieg and Vollmer, 2007). TLR4 expression has been investigated in tumor cells or cell lines, including gastric carcinoma, extranodal marginal zone B-cell lymphomas, pituitary epithelial tumor cell lines, hepatocellular carcinoma cells, colon cancer cells, and human prostate epithelial PC3 cells. Although TLR4 is expressed in numerous non-immune and tumor cells, the functional association of TLR4 with tumor progression requires further elucidation.

The potential association between TLR4 genetic polymorphisms and the risk of breast, gastric, prostate, ovarian, HCC, cervical, and colorectal cancers has been investigated (Zhu et al., 2013; Zidi et al., 2014a,b; Jiang et al., 2014; Zhou et al., 2014; Kopp et al., 2015). Li et al. (2014) found that the TLR4-2081G/A polymorphism affected the risk of gastric carcinogenesis and may play a protective role against Helicobacter pylori infection. Zidi et al. (2014b) found that a specific gene variant in TLR4 (Asp299Gly) increased susceptibility to cervical cancer in Tunisian women. In the study by Wang et al. (2014), cases of ovarian cancer were analyzed with regard to the Asp299Gly and Thr399lle mutations in the TLR4 gene. Their results indicated that these mutations occurred at a lower frequency in ovarian cancer patients than healthy controls. However, Priyadarshini et al. (2013) found that the same mutations were associated with a higher risk for developing prostate cancer. Theodoropoulos et al. (2012) found that the Asp299Gly mutation in the TLR4 gene might confer an increased susceptibility to breast cancer development. However, there has been little research on the association between the TLR4$729 \mathrm{G} / \mathrm{C}$ polymorphism and the risk of bladder cancer.

In the present study, we found that there was a significant difference in the distribution of the TLR4-729G/C genotype between bladder cancer patients and healthy controls. The frequency of allele $\mathrm{C}$ was significantly higher in the bladder cancer group compared to the control group. Our analysis showed that the GC and CC genotypes were significantly associated with increased bladder cancer risk when the $G G$ genotype served as a reference. The $G C+C C$ genotype was significantly associated with increased bladder cancer risk under the dominant model. Furthermore, carriers of the $\mathrm{C}$ allele were likely to have an increased risk of developing bladder cancer. In summary, we report a statistically significant association between the TLR4$729 \mathrm{G} / \mathrm{C}$ polymorphism and the risk of developing bladder cancer in a Chinese population.

\section{Conflicts of interest}

The authors declare no conflict of interest.

\section{ACKNOWLEDGMENTS}

Research supported by the Hunan Provincial Natural Science Foundation of China (Grant \#14JJ3044), and the Science Foundation of Health and Family Planning Commission of Hunan Province (Grant \#B2012-032). 


\section{REFERENCES}

Akira S and Takeda K (2004). Toll-like receptor signalling. Nat. Rev. Immunol. 4: 499-511.

Akira S, Takeda K and Kaisho T (2001). Toll-like receptors: critical proteins linking innate and acquired immunity. Nat. Immunol. 2: $675-680$

Balkwill F and Coussens LM (2004). Cancer: an inflammatory link. Nature 431: 405-406.

Hahn WC and Weinberg RA (2002). Modelling the molecular circuitry of cancer. Nat. Rev. Cancer 2: 331-341.

Horie Y, Meguro A, Ota M, Kitaichi N, et al. (2009). Association of TLR4 polymorphisms with Behcet's disease in a Korean population. Rheumatology 48: 638-642.

Ishihara S, Rumi MA, Kadowaki Y, Ortega-Cava CF, et al. (2004). Essential role of MD-2 in TLR4-dependent signaling during Helicobacter pylori-associated gastritis. J. Immunol. 173: 1406-1416.

Jiang ZC, Tang XM, Zhao YR and Zheng L (2014). A functional variant at miR-34a binding site in toll-like receptor 4 gene alters susceptibility to hepatocellular carcinoma in a Chinese Han population. Tumour Biol. 35: 12345-12352.

Kopp TI, Andersen V, Tjonneland A and Vogel U (2015). Polymorphisms in NFKB1 and TLR4 and interaction with dietary and life style factors in relation to colorectal cancer in a Danish prospective case-cohort study. PloS One 10: e0116394.

Krieg AM and Vollmer J (2007). Toll-like receptors 7, 8, and 9: linking innate immunity to autoimmunity. Immunol. Rev. 220: 251-269.

Levy S, Sutton G, Ng PC, Feuk L, et al. (2007). The diploid genome sequence of an individual human. PLoS Biol. 5: e254.

Li P, He CY, Xu Q, Sun LP, et al. (2014). Effect of the -2081G/A polymorphism of the TLR4 gene and its interaction with Helicobacter pylori infection on the risk of gastric cancer in Chinese individuals. Genet. Test. Mol. Biomarkers 18: 610-615.

Priyadarshini A, Chakraborti A, Mandal AK and Singh SK (2013). Asp299Gly and Thr399lle polymorphism of TLR-4 gene in patients with prostate cancer from North India. Indian J. Urol. 29: 37-41.

Shariat SF, Sfakianos JP, Droller MJ, Karakiewicz PI, et al. (2010). The effect of age and gender on bladder cancer: a critical review of the literature. BJU Int. 105: 300-308.

Siegel RL, Miller KD and Jemal A (2015). Cancer statistics, 2015. CA Cancer J. Clin. 65: 5-29.

Theodoropoulos GE, Saridakis V, Karantanos T, Michalopoulos NV, et al. (2012). Toll-like receptors gene polymorphisms may confer increased susceptibility to breast cancer development. Breast 21: 534-538.

Wang AC, Wu FX, Gao YS and Sheng XG (2014). Toll-like receptor 4 single-nucleotide polymorphisms Asp299Gly and Thr399lle in ovarian cancers. Oncol. Lett. 8: 438-440.

Wu X, Ros MM, Gu J and Kiemeney L (2008). Epidemiology and genetic susceptibility to bladder cancer. BJU Int. 102: 1207-1215.

Zhou Q, Wang C, Wang X, Wu X, et al. (2014). Association between TLR4 (+896A/G and +1196C/T) polymorphisms and gastric cancer risk: an updated meta-analysis. PloS One 9: e109605.

Zhu L, Yuan H, Jiang T, Wang R, et al. (2013). Association of TLR2 and TLR4 polymorphisms with risk of cancer: a metaanalysis. PloS One 8: e82858.

Zidi S, Verdi H, Yilmaz-Yalcin Y, Yazici AC, et al. (2014a). Impact of Toll-like receptors 2/3/4/9, IL-1-alpha/beta and TNF-alpha polymorphisms in cervical cancer susceptibility in Tunisia: Genetic polymorphisms implicated in the occurence of cervical cancer. Pathol. Oncol. Res. May 17, 2014.

Zidi S, Verdi H, Yilmaz-Yalcin Y, Yazici AC, et al. (2014b). Involvement of Toll-like receptors in cervical cancer susceptibility among Tunisian women. Bull. Cancer 101: E31-E35. 